\title{
Layer-By-Layer Assembly of Enzymes and Nanoparticles onto Cellulose Support
}

Semerdzhieva $\mathbf{V}^{1}$, Raykova $\mathbf{R}^{1}$, Marinkova $\mathrm{D}^{1 *}$, Yaneva $\mathbf{S}^{2}$, Chernev $\mathbf{G}^{2}$ and Iliev $\mathbf{I}^{2}$

${ }^{1}$ Department of Biotechnology, University of Chemical Technology and Metallurgy, Bulgaria

${ }^{2}$ Department of Electronics, Technical University, Bulgaria

\begin{abstract}
Multilayered films of cellulose nanoparticles (NFC's) and modified multi-walled carbon nanotubes (MWCNT's) were assembled by means of alternate electrostatic adsorption with positively charged poly(ethyleneimine) (PEI) onto cellulose support. The free carboxylic groups of NFC's and MWCNT's were coupled with ethylenediamine. Glucose oxidase and laccase were immobilized by means of Schiff base reaction between aldehyde groups of glutaraldehyde and the free amino sites of the proteins.

The immobilized enzymes on the surface of nanoparticles have higher value for the specific activity compared to the enzymes immobilized directly on the cellulose surface indicating the stabilization of the proteins by the nanoparticles. The kinetics of the enzymes, catalyzed reactions and reusability of the enzymes were investigated and were showing better properties for enzymes cross-linked with glutaraldehyde. After 5 days the initial enzyme activity of glucose oxidase was around $85 \%$, but the initial enzyme activity of laccase was $60 \%$. The kinetic investigations of the immobilized enzymes showed no significant difference in Michaelis constant but the maximum reaction rate is decreased.
\end{abstract}

Keywords: Layer-by-layer; Glucose oxidase; Laccase; Enzyme kinetics; Nanocellulose; Multi-walled carbon nanotubes

\section{Introduction}

Due to need of cheap, easy to use, biocompatible and biodegradable materials for biosensors and biofuel cell electrodes cellulose could offer some new alternatives as a material. Cellulose is the most widely spread organic polymer found in nature, since it constitutes the main component of the membrane of plant cell. It is well-known that cellulose is a very important and fascinating biopolymer and an almost inexhaustible and renewable raw material [1].

Nanomaterials have increased a great attention by their properties like high surface to volume ratio, which makes them suitable for enzyme immobilization. Nanoparticles like multi-walled carbon nanotubes (MWCNT's) and gold nanoparticles (AuNp's) could provide a direct electron transfer, which is important for the construction of enzyme-based biosensors and biofuel cells. On the other hand cellulose nanoparticles like nanofibrillated cellulose and cellulose nanocrystals can be applied as a support material with good chemical and mechanical properties for the preparation of carriers for enzyme immobilization.

Nanometer-scale cellulose fibers, or nanocellulose, are emerging materials for various advanced applications. Nanocellulose can be obtained through two approaches: 1 . Bottom- up or 2. Top-down. In the bottom-up approach cellulose is produced by fermentation of low molecular weight sugars using cells of Acetobacter. These cellulose fibers, more commonly known as bacterial cellulose, are inherently nanofibrillar. With regards to nanocellulose produced using the topdown approach, lingo (cellulosic) biomass such as wood pulp are either treated with strong ultrasound passing through high-pressure homogenisers or through grinders to reduce the size of these fibers to the nanometer scale. Wood-based nanocellulose is more commonly known as cellulose nanofibers [2].

A new approach for production of cellulose nanoparticles uses the TEMPO (2,2,6,6-tetramethylpiperidine-1-oxyl radical) -NaBr-NaClOsystem. Mostly individualized cellulose nanofibers dispersed in water can be obtained by TEMPO-mediated oxidation of native cellulose and successive mechanical [3] or ultrasound [4] treatment of the oxidized cellulose in water. The TEMPO-mediated oxidation of native cellulose at $\mathrm{pH} 10$ is optimum for shortening the oxidation time. The cellulose nanofibers obtained are 3-4 $\mathrm{nm}$ in width and a few microns in length. The carboxylate groups formed on each cellulose nanofiber surface in a high density (ca. 3.4 groups $/ \mathrm{nm}^{2}$ or $0.54 \mathrm{C} / \mathrm{m}^{2}$ ) allow for quite stable dispersions. Both never-dried and once-dried celluloses give similar cellulose nanofiber/water dispersion when the conditions described above are satisfied. The original cellulose crystallinity is maintained during TEMPO-mediated oxidation and the successive stirring, cellulose nanofibers with crystallinities of $65-95 \%$ can be obtained using this method [3].

The strength and toughness of cellulose nanofibril networks can be combined with the electrical conductivity of carbon nanotubes. If multiwalled carbon nanotubes (MWCNT) are mixed with nanofibrillated cellulose (NFC) in aqueous suspension and filtered into tough nanopaper structures with up to $17 \mathrm{wt} \%$ of MWCNT commingled with NFC nanofibrils. Carbon nanotubes can be surface treated with a surfactant, and homogenous suspensions of carbon nanotubes in water miscible with the NFC suspension can be obtained.

The electrical conductivity of this $\mathrm{NFC/carbon}$ nanotubes nanopaper composition increases 4 orders of magnitude compared with neat NFC nanopaper, since a continuous percolated MWCNT phase is formed [5].

Conducting NFC aerogels have been made by functionalizing with

*Corresponding author: Marinkova D, Department of Biotechnology, University of Chemical Technology and Metallurgy, Bulgaria, Tel: +359 2816 3110; E-mail: dmarinkova@yahoo.com

Received November 14, 2018; Accepted December 21, 2018; Published December 31, 2018

Citation: Semerdzhieva V, Raykova R, Marinkova D, Yaneva S, Chernev G, et al. (2018) Layer-By-Layer Assembly of Enzymes and Nanoparticles onto Cellulose Support. J Biosens Bioelectron 9: 263. doi: 10.4172/2155-6210.1000263

Copyright: (c) 2018 Semerdzhieva V, et al. This is an open-access article distributed under the terms of the Creative Commons Attribution License, which permits unrestricted use, distribution, and reproduction in any medium, provided the original author and source are credited. 
conjugated polymers or by mixing with carbon nanotubes. Recently a robust and rapid method has been shown for the layer-by-layer assembly of functional polymers and nanoparticles on cross-linked nanocellulose aerogels with a porosity close to $99 \%$, high strength, and nanoscale shape integrity in water [6].

Layer by layer (LbL) assembly is a generic technique for coating functional materials onto surfaces aiming improvement of their properties, and a large number of applications based on this technique have been accomplished including coating of cellulose aerogels [7-9].

In this study native cellulose was used as a substrate and LbL technique was applied for improvement of its properties aiming toughness, conductivity and high surface area. The obtained materials were used as a matrix for enzyme immobilization. Two model enzymes were applied-laccase and glucose oxidase. These enzymes are widely used in the field of biosensor and biofuel cells construction [10-13]. The activity, reusability and the kinetics of the enzyme reactions were investigated.

\section{Materials and Methods}

\section{Chemicals}

Laccase from Trametes versicolor, glucose oxidase (GOx) from Aspergillus niger, glucose monohydrate, poly(ethyleneimine) solution with molecular weight 1200 -1300 Da (PEI), cellulose, glutaraldehyde, multi-walled carbon nanotubes, $>90 \%$ carbon basis, DxL $110-170$ nm x 5-9 nm, 2,2'-Azino-bis(3-ethylbenzothiazoline-6-sulfonic acid) diammonium salt $98 \%$ (ABTS), $\mathrm{NaBr}, \mathrm{NaClO}$, Triton X-100 were purchased from Sigma Aldrich. 2,2,6,6- Tetramethyl-1-piperidinyloxy, free radical 98\% (TEMPO), 1-(3-Dimethylaminopropyl)-3ethylcarbodiimide hydrochloride, $98+\%$ (EDC) were purchased from Alfa Aesar, Ethylenediamine 99\%, extra pure was purchased from Acros Organics. All other reagents were with quality pure for analysis [14-20].

\section{Determination of the total protein}

The total protein content of the free enzymes was determined by method of Lowry et al. using bovine serum albumin as a standard [19]. The protein content of the immobilized enzymes was determined by modified Lowry method $[21,22]$.

Reagents for the assay were prepared as follows: Solution A. $2 \%$ $\mathrm{Na}_{2} \mathrm{CO}_{3}$ in $0.1 \mathrm{~N} \mathrm{NaOH}$; Solution B. $1 \% \mathrm{Na}$ - Tartrate in $\mathrm{H}_{2} \mathrm{O}$; Solution C. $0.5 \% \mathrm{CuSO}_{4} .5 \mathrm{H}_{2} \mathrm{O}$; Solution D was prepared by $0.5 \mathrm{ml}$ of $\mathrm{B}, 0.5 \mathrm{ml}$ of $\mathrm{C}$ and $50 \mathrm{ml}$ of $\mathrm{A}$. The matrix with immobilized enzyme was washed with d. $\mathrm{H}_{2} 0$ after the immobilization and added to a $5 \mathrm{ml}$ of $\mathrm{D}$. It was vigorously mixed by magnetic stirrer for $2.5 \mathrm{~h}$ and after, $0.5 \mathrm{ml} 1 \mathrm{~N}$ Folin-Ciocalteau's phenol reagent were added. After mixing for 40 min the absorption was measured at $\lambda=750 \mathrm{~nm}$. The blank sample was prepared as washing of an empty matrix for immobilization, than mixing for $2.5 \mathrm{~h}$ in reagent $\mathrm{D}$ and $0.5 \mathrm{ml} \mathrm{N}$ Folin-Ciocalteau's phenol reagent were added followed by mixing for $40 \mathrm{~min}$.

\section{Investigation of the activity of the free laccase}

One unit of laccase activity was defined as the enzyme amount oxidizing $1 \mu \mathrm{mol}$ substrate per min at $30^{\circ} \mathrm{C}$. The necessary enzyme concentrations were selected according to obtain extinction of 0.2-1 approximately after $5 \mathrm{~min}$ and was used in all photometric measurements applying common test conditions. The ABTS $(\varepsilon 420-36$
mM-1 cm-1) test was performed in $50 \mathrm{mM}$ acetate buffer $\mathrm{pH} 5.0$ with $0.25 \mathrm{mM}$ final concentration of the substrate [14].

\section{Investigation of the activity of the free glucose oxidase}

One unit of glucose oxidase activity was defined as the enzyme amount oxidizing $1 \mu \mathrm{mol}$ substrate per min in $25^{\circ} \mathrm{C}$. The concentration of enzyme was $0.01 \mathrm{mg} / \mathrm{ml}$. The concentration of substrate - glucose was $0.1 \mathrm{M}$ and the molar absorption coefficient for $\mathrm{H}_{2} \mathrm{O}_{2}$ is $\varepsilon_{460}-11.3 \mathrm{mM}^{-1}$ $\mathrm{cm}^{-1}$. The experimental tests were performed in $0.1 \mathrm{M}$ phosphate buffer with $\mathrm{pH} 6.0$ mixed with o-dianisidine in ratio 12:0.1. For determination of glucose oxidase activity was used the enzyme solution of indicating enzyme peroxidase containing $60 \mathrm{U} / \mathrm{ml}$ was used [15,22].

\section{Determination of the kinetic parameters of the free enzymes}

Michaelis-Menten model and linearization plot of LineweaverBurk were used for determination of the maximum reaction rate $\mathrm{V}_{\text {}}$ and the Michaelis constant $\mathrm{K}_{\mathrm{M}}$. For this purpose the initial rate of the enzyme reactions was determined with different concentrations of the substrate. The Lineweaver-Burk plot was used for the calculation of the kinetic parameters $\mathrm{V}_{\max }, \mathrm{K}_{\mathrm{M}}$ and $\mathrm{k}_{\text {cat }} / \mathrm{K}_{\mathrm{M}}$.

\section{Determination of the Damköhler numbers}

From the values for $\mathrm{K}_{\mathrm{M}}$ and $\mathrm{V}_{\max }$ the Damköhler numbers (Da) were determined as follows:

$\delta$ - thickness of the membrane, $[\mathrm{m}]$

Ds - Effective diffusive constant of the substrate, $\left[\mathrm{m}^{2} . \mathrm{s}^{-1}\right]$

$$
D a=\frac{V_{\text {max' }^{\prime} a p p}}{D s / \delta^{-2} \cdot K m^{\prime} a p p}
$$

\section{LbL immobilization of the enzymes onto Whatman 1 paper with PEI}

The possibility for LbL assembly of the enzymes with polyelectrolyte PEI was investigated layering different combination of enzyme/PEI layers as follows: 1 . One layer of PEI followed by one layer of enzyme (PEI-E); 2. PEI layer, enzyme layer followed by another PEI layer (PEI-E-PEI); 3. One layer of PEI, one layer enzyme, second layer PEI and second layer of enzyme (PEI-E-PEI-E); 4. Eight successive layers alternating PEI and enzyme (PEI-E-PEI-E-PEI-E-PEI-E). For that purpose $30 \mathrm{~mm}$ pieces were cut and the weight was measured. Then the pieces were washed with water and $10 \mathrm{ml}$ of $2,5 \mathrm{~g} / \mathrm{l}$ PEI were added to each paper. After $20 \mathrm{~min}$ at room temperature the paper was washed $3 \times 20$ min with water. This was followed by adding enzyme solutions to the paper and shaking again for $20 \mathrm{~min}$ at $4^{\circ} \mathrm{C}$. This procedure was followed by washing $3 \times 20$ min with water. This formed one layer of enzyme. The procedure was repeated until the desired amount of layers were achieved.

\section{LbL immobilization enzymes onto Whatman 1 with PEI and glutaraldehyde}

The possibility for LbL assembly of the enzymes with polyelectrolyte PEI and cross-linking with glutaraldehyde was investigated layering different combination of PEI-glutaraldehyde-enzyme layers as follows: 1. One layer of PEI, second layer of glutaraldehyde followed by one layer of enzyme (PEI-GA-E); 2. PEI layer, glutaraldehyde layer, enzyme layer followed by another glutaraldehyde layer (PEI-GA-E-GA); 3. One layer of PEI, second layer of glutaraldehyde, one layer enzyme, second 
layer glutaraldehyde and second layer of enzyme (PEI-GA-E-GA-E); 4. One layer of PEI-eight successive layers alternating glutaraldehyde and enzyme (PEI-GA-E-GA-E-GA-E-GA-E). For that purpose 30 $\mathrm{mm}$ pieces were cut and the weight was measured. Then the pieces were washed with water and $10 \mathrm{ml}$ of $2,5 \mathrm{~g} / \mathrm{l} \mathrm{PEI}$ are added to each paper. After $20 \mathrm{~min}$ at room temperature the paper was washed $3 \mathrm{x}$ $20 \mathrm{~min}$ with water. After that the paper was placed in $10 \mathrm{ml} 0,025 \%$ glutaraldehyde for $4 \mathrm{~h}$ at room temperature followed by washing $3 \times 20$ min with water. This was followed by adding enzyme solutions to the paper and shaking again for $4 \mathrm{~h}$ at $4^{\circ} \mathrm{C}$. This procedure was followed by washing $3 \times 20$ min with water. After that the paper was placed in 10

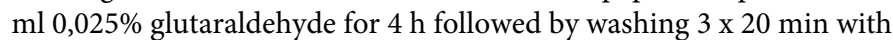
water [16].

\section{TEMPO-Mediated oxidation of native cellulose}

TEMPO was used in concentration $0.11 \mathrm{mM} / \mathrm{g}$ cellulose fibre and $\mathrm{NaBr}$ was used in concentration of $0.617 \mathrm{mM} / \mathrm{g}$ cellulose fibre. Both were diluted with deionized water $(50 \mathrm{ml})$ before added to the fiber suspension. The $\mathrm{pH}$ of the fiber slurry was adjusted to 10.0-10.2 with $0.5 \mathrm{M} \mathrm{NaOH}$ or $0.5 \mathrm{M} \mathrm{HCl}$ using $\mathrm{pH}$-stat. The TEMPO-mediated oxidation was started by the addition of $\mathrm{NaOCl}(3.75 \mathrm{mM} / \mathrm{g}$ cellulose fibre) at $25^{\circ} \mathrm{C}$. The reaction was stopped after $90 \mathrm{~min}$ by the addition of $50 \mathrm{ml}$ ethanol and the final $\mathrm{pH}$ of the solution was adjusted to 7.0 by adding $0.5 \mathrm{M} \mathrm{NaOH}$ or $0.5 \mathrm{M} \mathrm{HCl}$ as required [3].

Measurement of the carboxyl content of the native cellulose and measurement of the carboxyl content of the TEMPO-oxidised cellulose and the post-oxidized cellulose.

The samples were rinsed 3 times with $0.1 \mathrm{~N} \mathrm{HCl}$ and washed thoroughly with water. Then the samples were placed in a flask, $50 \mathrm{ml}$ of water and three drops of $0.05 \%$ phenolphthalein were added. The amount of carboxyl groups was determined via direct titration with standard solution of $\mathrm{NaOH}(0.01 \mathrm{~N})$.

\section{Post-oxidation of cellulose with $\mathrm{NaClO}_{2}$}

The Post-oxidation with $\mathrm{NaClO}_{2}$ was carried out in acetic acid/ sodium hydroxide buffer $(\mathrm{pH} 4.5-5.0)$ at $70^{\circ} \mathrm{C}$ to convert the aldehyde groups, which were produced during the TEMPO-mediated oxidation, to carboxyl groups. In this process $2 \mathrm{~g}$ of the oxidized pulp were suspended in $160 \mathrm{ml}$ of de-ionized water in a tightly closed $250 \mathrm{ml}$ glass bottle. This was followed by the addition and mixing, sequentially of 20 $\mathrm{ml}$ of $34 \mathrm{~g} / \mathrm{l} \mathrm{NaClO}$ and $20 \mathrm{ml}$ of acetic acid/sodium hydroxide buffer, giving a final volume of $200 \mathrm{ml}$ of the reaction mixture. The mixture was kept in a water bath at $70^{\circ} \mathrm{C}$ for $2 \mathrm{~h}$ after which it was cooled, filtered and washed thoroughly with de-ionized water [3].

\section{Production of nanocellulose (NFC)}

The TEMPO - oxidized cellulose $(0.3 \mathrm{~g})$ was suspended in deionized water $(300 \mathrm{ml})$ at $0.1 \%$ concentration. The suspension was treated in an ultrasonic bath at $40 \mathrm{kHz}$ and at maximum intensity setting for $1 \mathrm{~h}[4,17]$.

\section{Purification and modification of MWCNT}

Multi-walled carbon nanotubes were purified prior to use. It is well known that nitric acid is very effective at dissolving metal particles. On the other hand hydrochloric acid is suitable for dissolving metal oxides. As received the MWCNT's were purified with $37 \% \mathrm{HCl}$ for $1 \mathrm{~h}$ at $60^{\circ} \mathrm{C}$. After that the tubes were centrifuged and placed in a $3: 1 \mathrm{HNO}_{3}: \mathrm{H}_{2} \mathrm{SO}_{4}$ for $1 \mathrm{~h}$ at room temperature. The tubes were cleaned with vacuum filtration using PVDF membrane with pore size $0.22 \mu \mathrm{m}$ until a neutral
$\mathrm{pH}$ was achieved. Then the $\mathrm{pH}$ was adjusted to 8.0 in order to obtain a net negatively charged carboxylate anions. Purified MWCNT were dispersed in water using Triton X-100 (0.13\%) in concentration of 5 $\mathrm{mg} / \mathrm{ml}$. The sample was then sonicated until stable suspension without any agglomerates was obtained [18-20].

\section{Layer-by-layer assembly of enzymes and nanoparticles onto cellulose}

Filter paper Whatman 1 was used for this experiment and $30 \mathrm{~cm}$ of circles were cut and washed with water before placed in $10 \mathrm{ml} 2.5$ $\mathrm{mg} / \mathrm{ml}$ PEI with molecular weight $1.2 \mathrm{kDa}$. After $20 \mathrm{~min}$ the probes were washed $3 \times 10 \mathrm{~min}$ with water. A second layer of nanofibrillated cellulose (NFC's) was prepared as the probes were placed in $10 \mathrm{ml}$ of NFC's suspension for 20 min and washed afterwards $3 \times 20$ min with water. Four initial layers of were prepared with this procedure respectively PEI-NFC's-PEI-NFC's. After that a $5^{\text {th }}$ layer of PEI was added followed by 6 th layer of particles. The $6^{\text {th }}$ layer consisted of either NFC's, oxidised MWCNT's or mixture of 5\% oxidised MWCNT's in $0.1 \mathrm{~g} / \mathrm{l} \mathrm{NFC's.} \mathrm{After} \mathrm{washing} 3 \times 20 \mathrm{~min}$ with water the material was dried at $60^{\circ} \mathrm{C}$

Both NFC's and MWCNT's contained carboxylic groups which were coupled with ethylenediamine using the procedure of carbodiimide coupling (50 $\mathrm{mM}$ EDC and $5 \mathrm{mM}$ ethylenediamine at RT for $1 \mathrm{~h}$ ). After washing $10 \mathrm{ml}$ of $0.025 \%$ glutaraldehyde were added to each sample for $4 \mathrm{~h}$ at RT. The samples were washed $3 \times 20 \mathrm{~min}$ with water and placed in $1 \mathrm{mg} / \mathrm{ml}$ enzyme solutions for $4 \mathrm{~h}$ at $4^{\circ} \mathrm{C}$. After washing another layer of glutaraldehyde was added followed by washing $3 \times 20$ min with water.

\section{Scanning electron microscopy}

The synthesized matrices were visualized by scanning electron microscopy (SEM) with magnification 2, 10 and 100 micrometers.

\section{Results and Discussion}

\section{Activity of the free enzymes}

The specific activity of the free enzymes was determined. The activity of GOx was determined from the reaction progress curve shown in Figure 1. The activity of the free laccase was determined from the reaction progress curve shown in Figure 2.

\section{Determination of the kinetic parameters of the free enzymes}

The kinetic parameters were determined using the Michaelis-

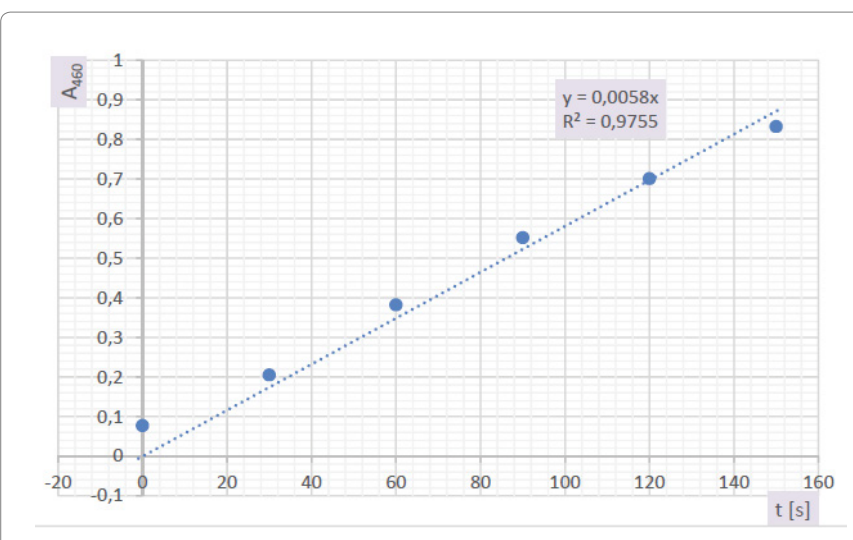

Figure 1: Reaction progress of the free GOx from A.niger. The value for the specific activity of the enzyme is $18.9 \mathrm{U} / \mathrm{mg}$. 
Citation: Semerdzhieva V, Raykova R, Marinkova D, Yaneva S, Chernev G, et al. (2018) Layer-By-Layer Assembly of Enzymes and Nanoparticles onto Cellulose Support. J Biosens Bioelectron 9: 263. doi: 10.4172/2155-6210.1000263

Page 4 of 8

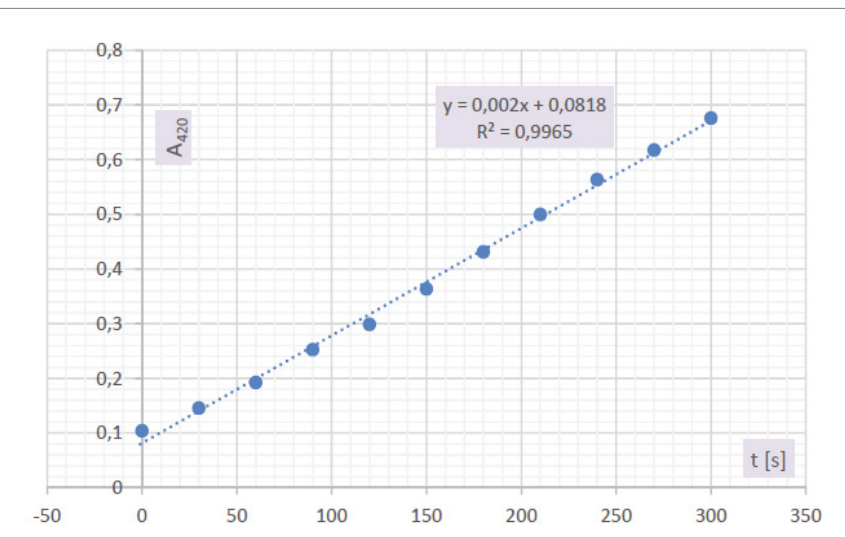

Figure 2: Reaction progress of the free laccase from T.versicolor. The value for the specific activity of the enzyme is is $3.9 \mathrm{U} / \mathrm{mg}$.

\begin{tabular}{|c|c|c|}
\hline & Glucose oxidase & Laccase \\
\hline $\mathbf{K}_{\mathbf{M}}, \mathbf{M}$ & $3.26 .10^{-3}$ & $4.11 .10^{-4}$ \\
\hline Vmax, M.s-1 & $6.39 .10^{-7}$ & $1.11 .10^{-7}$ \\
\hline kcat, s-1 & 0.599 & 0.0571 \\
\hline kcat/KM, M-1.s-1 & 183.95 & 139.05 \\
\hline
\end{tabular}

Table 1: Kinetic parameters of the free GOx and laccase.

Menten model and the linearization method of Lineweaver-Burk. Table 1 presents the kinetic parameters of the free enzymes.

Activity of the enzymes assembled onto Whatman 1 paper with PEI. The activity was determined spectrophotometrically under constant shaking for the different possibilities of PEI-enzyme layers. The results were calculated from the data showed in Figure 3 for the glucose oxidase and from Figure 4 for the laccase. The values of the specific activity are summarized in Table 2 .

Activity of the enzymes assembled onto Whatman 1 paper with PEI and glutaraldehyde. The activity was determined spectrophotometrically under constant shaking for the different possibilities of PEI-glutaraldehyde-enzyme layers. The results were calculated from the data showed in Figure 5 for the glucose oxidase and from Figure 6 for the laccase. The values of the specific activity are summarized in Table 3.

With the LbL assembly of the enzymes with PEI considering the enzyme glucose oxidase had good initial activity but the enzyme showed fast deactivation with this method of immobilization. For that reason glutaraldehyde was added to the procedure of immobilization. Glutaraldehyde forms Schiff bases with the free amino groups of the enzymes and this crosslinking method can retain the stability. The efficiency of the immobilized was 1-2 orders smaller than the efficiency of the free enzyme. The value for Michaelis constant is in the same order as the value for the free enzyme indicating that the active site of the enzyme was not affected by the immobilization method.

In the case of LbL assembly of the enzymes with glutaraldehyde and $\mathrm{PEI}$ a lower value for KM for GOx compared to the value obtained with immobilization with PEI can be observed. A lower value of Michaelis constant slightly influenced of the upper layer of GA can be observed, but considering the two immobilized layers of laccase, higher velocity and efficiency when 2 layers of laccase-GA are present.

\section{Determination of the carboxyl content of the oxidized cellulose}

The molar concentration of the carboxyl groups is determined from the volume of the standard solution of $\mathrm{NaOH}$ used in the titration as follows:

Molar concentration $-\mathrm{COOH}$ groups $[\mathrm{mol} / \mathrm{g}]=\mathrm{V} . \mathrm{M} / 1000 . \mathrm{w}$, where

$\mathrm{w}$ [mg] - weight of the sample determined after drying to absolutely dry weight at $105^{\circ} \mathrm{C}$;

$\mathrm{V}[\mathrm{ml}]$ - titre value of the $\mathrm{NaOH}$ in the experiment; $\mathrm{M}$ [mol] molarity of the $\mathrm{NaOH}$.

On the Figure 7 is presented the amount of the carboxyl groups of the native cellulose, the TEMPO-oxidized cellulose and the postoxidized cellulose.

\section{SEM images}

On the Figure 8 is presented SEM images of paper coated with the

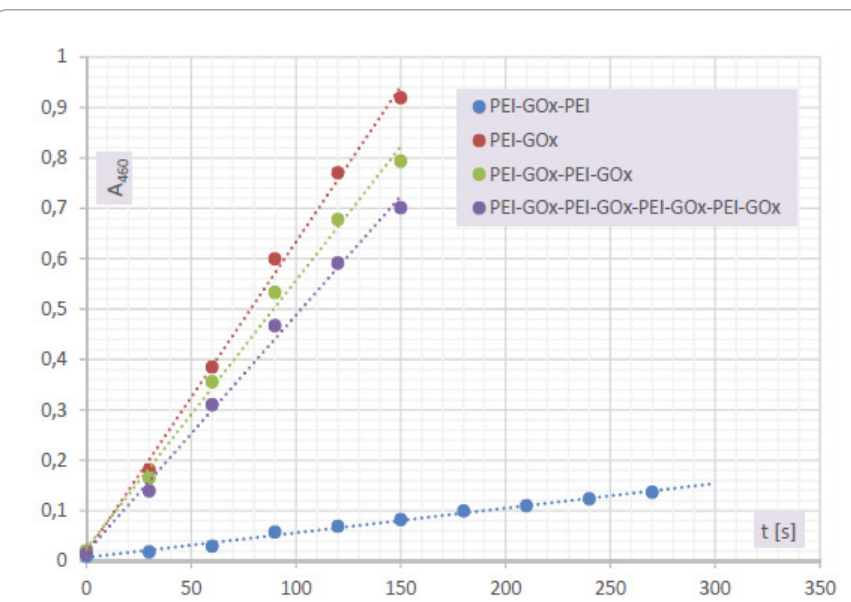

Figure 3: Reaction progress of GOx assembled onto Whatman 1 with PEI.

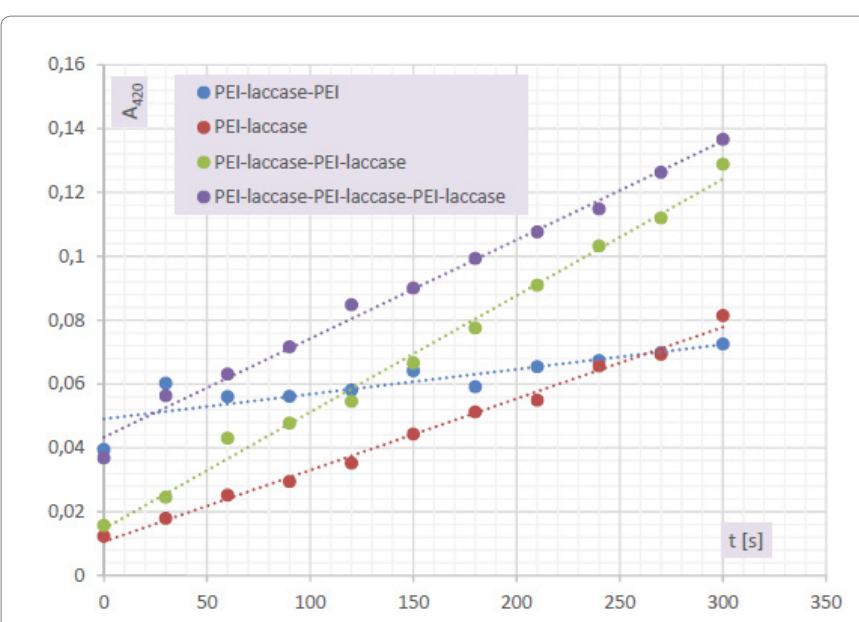

Figure 4: Reaction progress of laccase assembled onto Whatman 1 with PEI.

\begin{tabular}{|c|c|c|c|c|c|c|c|c|}
\hline & \multicolumn{4}{|c|}{ Glucose oxidase } & \multicolumn{3}{c|}{ Laccase } \\
\hline Layers & $\begin{array}{c}\text { PEI- } \\
\text { E-PEI }\end{array}$ & PEI-E & $\mathbf{2 x ( P E I - E )}$ & $\mathbf{4 x ( P E I - E )}$ & $\begin{array}{c}\text { PEI- } \\
\text { E-PEI }\end{array}$ & PEI-E & $\mathbf{2 x ( P E I - E )}$ & $\mathbf{4 x ( P E I - E )}$ \\
\hline $\begin{array}{c}\text { Specific } \\
\text { activity } \\
\text { U/mg }\end{array}$ & 0,016 & 0,146 & 0,089 & 0,071 & 0,00124 & 0,021 & 0,0235 & 0,0122 \\
\hline
\end{tabular}

Table 2: Specific activity of the enzymes assembled onto Whatman 1 with PEI. 
Citation: Semerdzhieva V, Raykova R, Marinkova D, Yaneva S, Chernev G, et al. (2018) Layer-By-Layer Assembly of Enzymes and Nanoparticles onto Cellulose Support. J Biosens Bioelectron 9: 263. doi: 10.4172/2155-6210.1000263

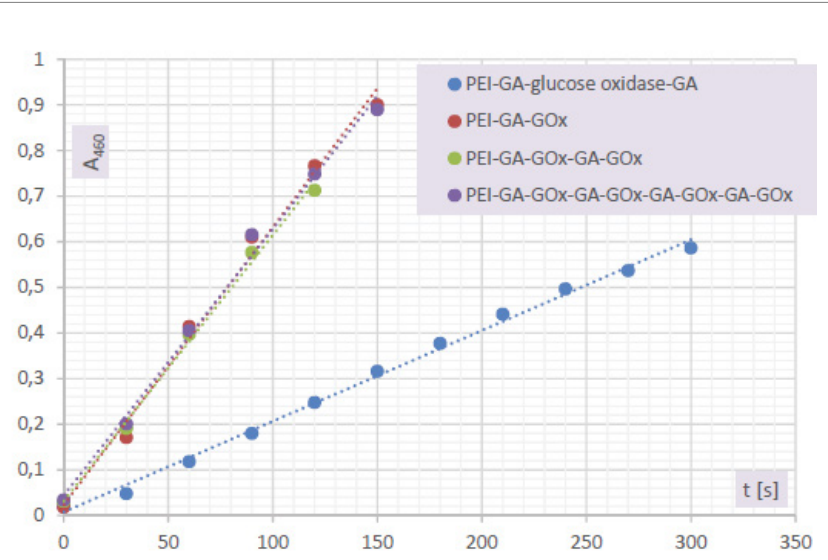

Figure 5: Reaction progress of GOx assembled onto Whatman 1 with glutaraldehyde (GA).

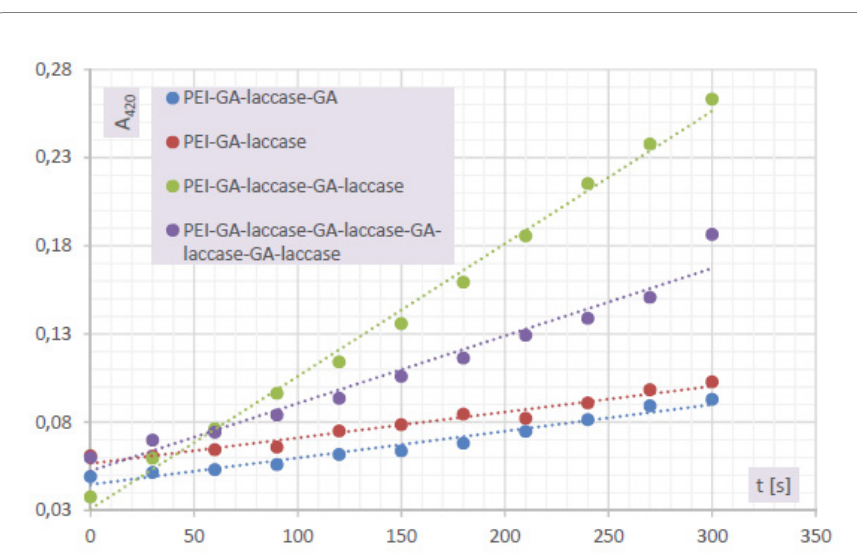

Figure 6: Reaction progress of laccase onto Whatman 1 with glutaraldehyde (GA).

\begin{tabular}{|c|c|c|c|c|c|c|c|c|}
\hline & \multicolumn{4}{|c|}{ Glucose oxidase } & \multicolumn{5}{c|}{ Laccase } \\
\hline Layers & $\begin{array}{c}\text { PEI- GA- } \\
\text { E-GA }\end{array}$ & $\begin{array}{c}\text { PEI- } \\
\text { GA-E }\end{array}$ & $\begin{array}{c}\text { PEI- } \\
\text { 2x(GA-E) }\end{array}$ & $\begin{array}{c}\text { PEI- } \\
\text { 4x(GA-E) }\end{array}$ & $\begin{array}{c}\text { PEI- GA- } \\
\text { E-GA }\end{array}$ & $\begin{array}{c}\text { PEI- } \\
\text { GA-E }\end{array}$ & $\begin{array}{c}\text { PEI- } \\
\text { 2x(GA-E) }\end{array}$ & $\begin{array}{c}\text { PEI- } \\
\text { 4x(GA-E) }\end{array}$ \\
\hline $\begin{array}{c}\text { Specific } \\
\text { activity U/ } \\
\text { mg }\end{array}$ & 0,0040 & 0,015 & 0,0093 & 0,0087 & 0,0087 & 0,0022 & 0,017 & 0,0071 \\
\hline
\end{tabular}

Table 3: Specific activity of the enzymes assembled onto Whatman 1 with PEI and glutaraldehyde.

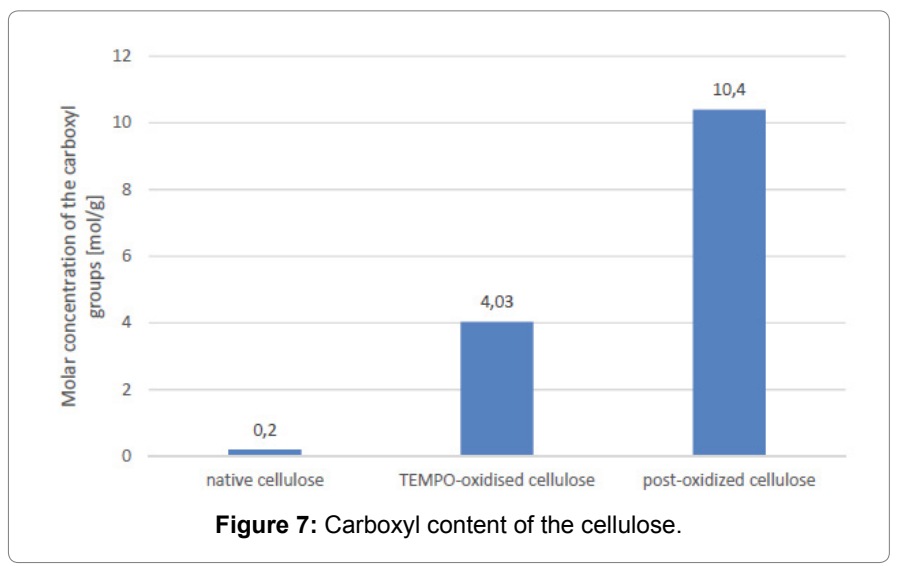

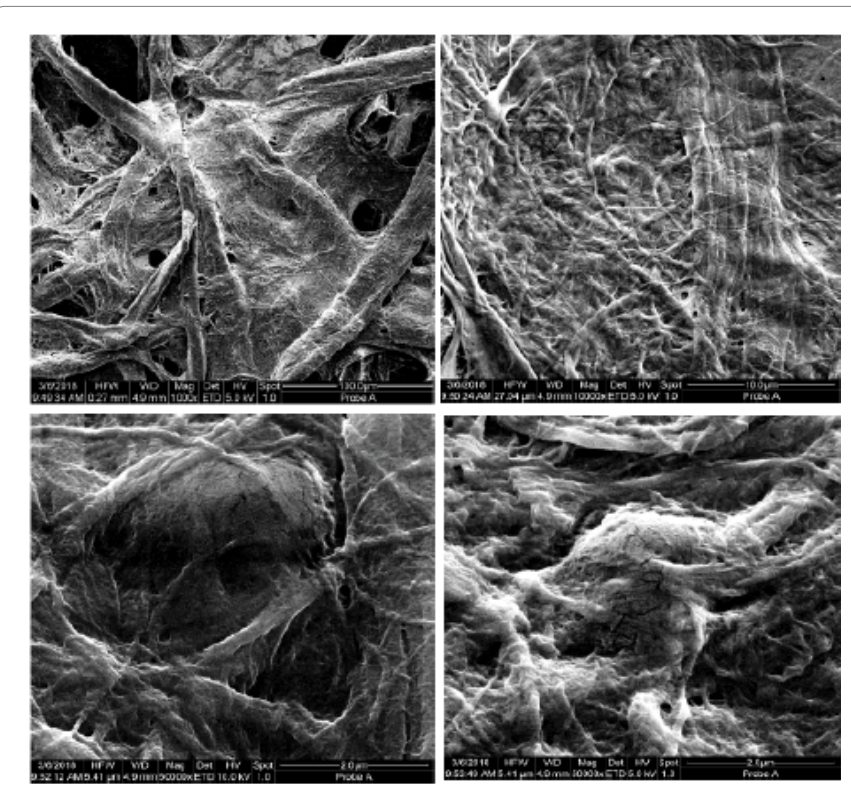

Figure 8: SEM image of paper coated with the following layers: PEI-NFC'sPEI-NFC's- PEINFC's.

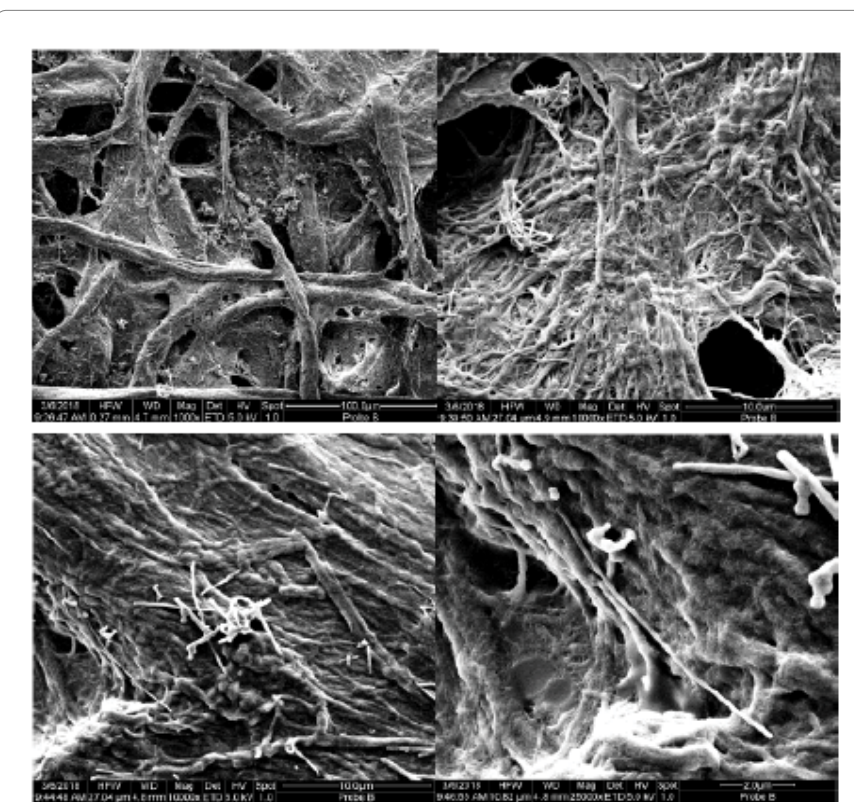

Figure 9: SEM image of paper coated with the following layers: PEI-NFC'sPEI-NFC's-PEIMWCNT's.

\begin{tabular}{|c|c|c|c|c|c|c|}
\hline & \multicolumn{3}{|c|}{ Glucose oxidase } & \multicolumn{3}{c|}{ Laccase } \\
\hline Nanoparticles & $\begin{array}{c}\text { NFC' } \\
\text { S }\end{array}$ & $\begin{array}{c}\text { MWCN } \\
\text { T's }\end{array}$ & $\begin{array}{c}\text { NFC's/ } \\
\text { MWCN } \\
\text { T's }\end{array}$ & NFC's & $\begin{array}{c}\text { MWCN } \\
\text { T's }\end{array}$ & $\begin{array}{c}\text { NFC's/ } \\
\text { MWCN } \\
\text { T's }\end{array}$ \\
\hline $\begin{array}{c}\text { Specific } \\
\text { activity U/mg }\end{array}$ & 0,0040 & 0,015 & 0,0093 & 0,0087 & 0,0087 & 0,0022 \\
\hline
\end{tabular}

Table 4: Specific activity of the enzymes assembled onto Whatman $1 /$ nanoparticles membranes.

following layers: PEI- NFC's-PEI-NFC's-PEI-NFC's, Figure 9 shows SEM image of paper coated with the following layers: PEI-NFC's-PEINFC's-PEI-MWCNT's and on Figure 10 is shown SEM image of paper 
Citation: Semerdzhieva V, Raykova R, Marinkova D, Yaneva S, Chernev G, et al. (2018) Layer-By-Layer Assembly of Enzymes and Nanoparticles onto Cellulose Support. J Biosens Bioelectron 9: 263. doi: 10.4172/2155-6210.1000263

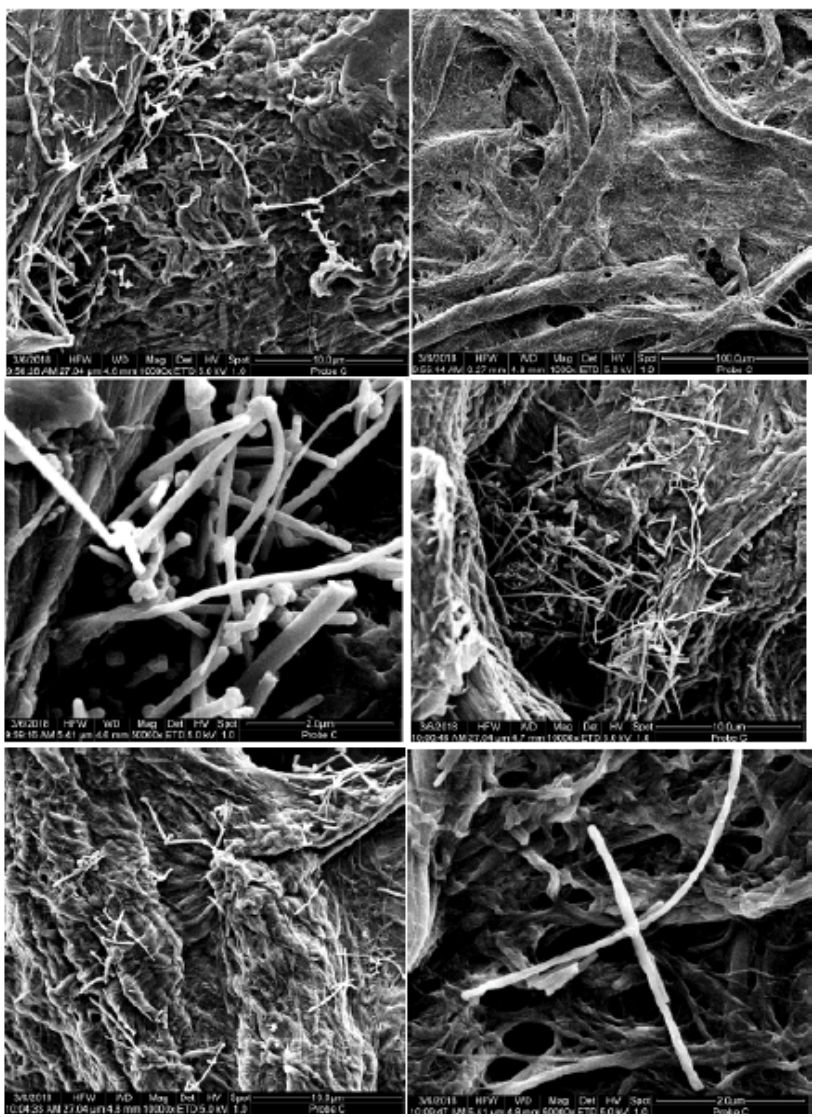

Figure 10: SEM image of paper coated with the following layers: PEI-NFC's-PEI-NFC's- PEINFC's/MWCNT's.

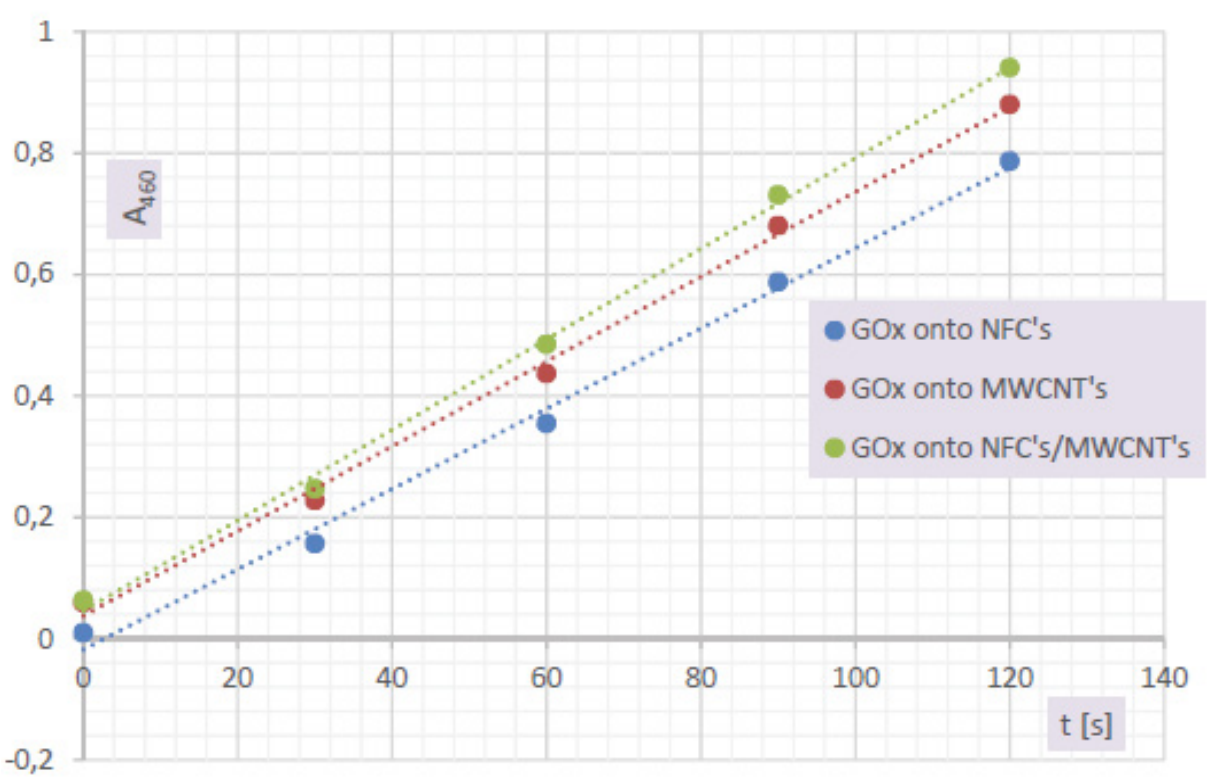

Figure 11: Reaction progress of GOx onto Whatman 1/nanoparticles membrane.

coated with the following layers: PEI-NFC's-PEI-NFC's-PEI-NFC's/ MWCNT's.

Activity of the enzymes assembled onto Whatman 1 coated

\section{with nanoparticles}

The activity was determined spectrophotometrically under constant shaking for the three different nano-layer assemblies. The results were 
Citation: Semerdzhieva V, Raykova R, Marinkova D, Yaneva S, Chernev G, et al. (2018) Layer-By-Layer Assembly of Enzymes and Nanoparticles onto Cellulose Support. J Biosens Bioelectron 9: 263. doi: 10.4172/2155-6210.1000263

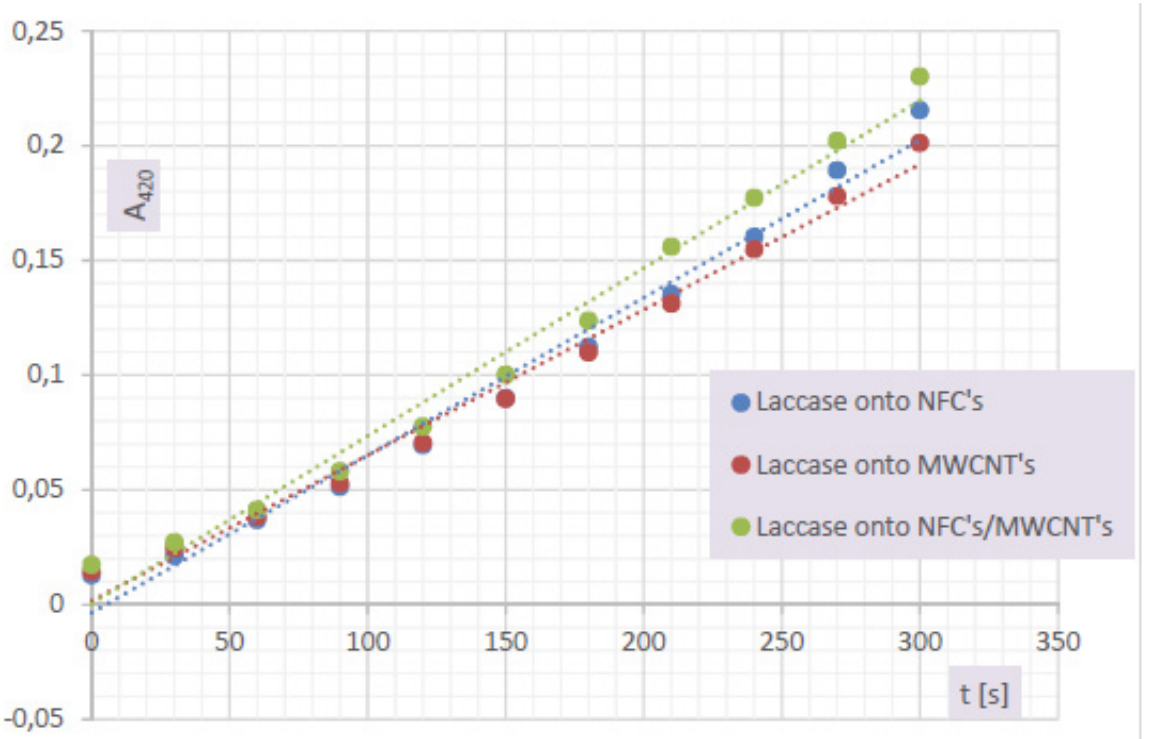

Figure 12: Reaction progress of laccase onto Whatman 1/nanoparticles membrane.

\begin{tabular}{|c|c|c|c|c|c|c|c|c|}
\hline \multicolumn{9}{|c|}{ Whatman 1} \\
\hline & \multicolumn{2}{|c|}{ Glucose oxidase } & & & \multirow{2}{*}{$\begin{array}{l}\text { Laccase } \\
\text { PEI-E-PEI }\end{array}$} & \multirow[b]{2}{*}{ PEI-E } & & \multirow[b]{2}{*}{ 4x(PEI-E) } \\
\hline Layers & PEI-E-PEI & PEI-E & 2x(PEI-E) & 4x(PEI-E) & & & 2x(PEI-E) & \\
\hline KM'app, M & 0.18 & 0.039 & 0.18 & 0.15 & $8.22 .10^{-4}$ & $2.00 .10^{-3}$ & $2.54 .10^{-3}$ & $3.38 .10^{-3}$ \\
\hline kcat'app, $\mathbf{s}^{-1}$ & $1.27 .10^{-1}$ & 2.64 & $1.02 .10^{-1}$ & 4.01 .10 & 1.49 & $4.00 .10^{-3}$ & $2.06 .10^{-3}$ & $8.08 .10^{-4}$ \\
\hline Vmax'app, M.s-1 & $1.67 .10^{-9}$ & $8.33 .10^{-9}$ & $2.75 .10^{-8}$ & $5.05 .10^{-8}$ & $1.67 .10^{-11}$ & $5.55 .10^{-10}$ & $4.17 .10^{-10}$ & $2.78 .10^{-10}$ \\
\hline kcat'app/KM'a, $\mathbf{M}^{-1} \cdot \mathbf{s}^{-1}$ & $6.81 .10^{-1}$ & 6.78 & $5.72 .10^{-1}$ & 2.58 & $1.82 .10^{3}$ & 2.00 & $8.10 .10^{-1}$ & $2.39 .10^{-1}$ \\
\hline $\mathrm{Da}$ & $2.94 .10^{10}$ & $7.04 .10^{11}$ & $5.05 .10^{11}$ & $1.07 .10^{12}$ & $1.02 .10^{11}$ & $1.39 .10^{12}$ & $8.23 .10^{11}$ & $4.12 .10^{11}$ \\
\hline Layers & PEI-GA-E-GA & PEI-GA-E & PEI-2x(GA-E) & PEI-4x(GA-E) & PEI-GA-E-GA & PEI-GA-E & PEI-2x(GA-E) & PEI-4x(GA-E) \\
\hline KM'app, M & 0.156 & 0.103 & 0.01 & 0.001 & $2.98 .10^{-4}$ & $1.01 .10^{-4}$ & $1.65 .10^{-4}$ & $1.39 .10^{-4}$ \\
\hline kcat'app, $\mathbf{s}^{-1}$ & $2.58 .10^{-4}$ & $3.39 .10^{-4}$ & $1.18 .10^{-4}$ & $1.11 .10^{-4}$ & $1.03 .10^{-4}$ & $7.06 .10^{-5}$ & $3.06 .10^{-4}$ & $1.39 .10^{-4}$ \\
\hline Vmax'app, M.s.'-1 & $5.55 .10^{-10}$ & $5.55 .10^{-10}$ & $3.33 .10^{-10}$ & $3.33 .10^{-10}$ & $8.33 .10^{-11}$ & $5.55 .10^{-11}$ & $1.67 .10^{-10}$ & $8.33 .10^{-11}$ \\
\hline kcat'app/KM'a, $\mathbf{M}^{-1} \cdot \mathbf{s}^{-1}$ & $1.65 .10^{-3}$ & $3.29 .10^{-3}$ & $1.19 .10^{-2}$ & $1.11 .10^{-2}$ & $3.47 .10^{-1}$ & $7.00 .10^{-1}$ & 1.86 & $9.99 .10^{-1}$ \\
\hline \multirow[t]{9}{*}{$\mathrm{Da}$} & $1.16 .10^{10}$ & $1.77 .10^{10}$ & $1.10 .10^{11}$ & $1.1 .10^{1}$ & $1.40 .10^{12}$ & $2.76 .10^{12}$ & $5.06 .10^{12}$ & $2.99 .10^{12}$ \\
\hline & \multicolumn{7}{|c|}{ Whatman 1/PEI/NFC's/PEI/NFC's/PEI } & \\
\hline & & NFC's & MWCNT's & $\begin{array}{c}\text { NFC's/ } \\
\text { MWCNT's }\end{array}$ & NFC's & MWCNT‘s & NFC's/ MWCNT's & \\
\hline & & \multicolumn{3}{|c|}{ Glucose oxidase } & \multicolumn{3}{|c|}{ Laccase } & \\
\hline & KM'app, M & $3.80 .10^{-3}$ & $4.98 .10^{-3}$ & $5.02 .10^{-3}$ & $2.99 .10^{-4}$ & $3.98 .10^{-4}$ & $2.56 .10^{-4}$ & \\
\hline & kcat'app, $\mathbf{s}^{-1}$ & $3.20 .10^{-2}$ & $3.19 .10^{-2}$ & $2.96 .10^{-2}$ & $2.73 .10^{-4}$ & $1.80 .10^{-4}$ & $2.45 .10^{-4}$ & \\
\hline & $\begin{array}{c}\text { Vmax'app, } \\
\text { M.s.-1 }\end{array}$ & $8.33 .10^{-9}$ & $8.33 .10^{-9}$ & $8.33 .10^{-9}$ & $4.17 .10^{-10}$ & $3.33 .10^{-10}$ & $2.78 .10^{-10}$ & \\
\hline & $\begin{array}{c}\text { kcat'app/ } \\
\mathrm{KM}^{\prime} \mathrm{a}, \mathrm{M}^{-1} \cdot \mathbf{s}^{-1}\end{array}$ & 8.4 & 6.4 & 5.9 & $2.73 .10^{-4}$ & $1.80 .10^{-4}$ & $2.45 .10^{-4}$ & \\
\hline & $\mathrm{Da}$ & $5.61 .10^{12}$ & $4.15 .10^{12}$ & $3.37 .10^{12}$ & $5.44 .10^{12}$ & $3.16 .10^{12}$ & $3.36 .10^{12}$ & \\
\hline
\end{tabular}

Table 5: Kinetic parameters of the LbL assembled enzymes and Damköhler numbers.

calculated from the data showed in Figure 11 for the glucose oxidase and from Figure 12 for the laccase. The values of the specific activity are summarized in Table 4.

\section{Kinetic parameters of the immobilized enzymes and Damköhler numbers}

The kinetic parameters were determined using Michaelis-Menten model and the parameters were calculated with the linearization method of Lineweaver-Burk. The Damköhler numbers were calculated with the specific diffusive coefficients for the glucose $\left(6.7 .10-10 \mathrm{~m}^{-1} \cdot \mathrm{s}^{-1}\right)$
[22] and the ABTS (4.4.10.-10 $\left.\mathrm{m}^{-1} \cdot \mathrm{s}^{-1}\right)$ [23]. The results are summarized in Table 5.

The Damköhler numers are indicating diffusive controlled reaction.

\section{Conclusion}

A novel matrices for enzyme immobilization were obtained by the electrostatic layer-by-layer assembly of nanoparticles onto cellulose support.

Considering the SEM images of the carriers it is visible that 
Citation: Semerdzhieva V, Raykova R, Marinkova D, Yaneva S, Chernev G, et al. (2018) Layer-By-Layer Assembly of Enzymes and Nanoparticles onto Cellulose Support. J Biosens Bioelectron 9: 263. doi: 10.4172/2155-6210.1000263

aggregates of MWCNT's are formed, when layer are immobilized as follows: PEI-NFC's-PEI-NFC's-PEI-MWCNT's but when the last layer consists of both NFC's in MWCNT's the tubes are scattered better on the surface.

When an assembly of enzymes and nanoparticles is obtained on the surface of the cellulose a higher values of the initial relative activity of glucose oxidase and good values of the initial relative activity of laccase can be observed. In comparison with the same method of immobilization and the immobilized enzymes onto paper the activity of glucose oxidase is 4 to 5 times higher than the value of the activity of the enzyme immobilized onto paper. Considering the results for laccase activity it shows no significant difference comparing the two different matrices. The enzyme GOx shows lower values of Michaelis than the values of GOx immobilized only onto paper and higher value for the reaction rate. In the case of laccase enzyme higher value for Michaelis constant compared to the enzyme immobilized onto paper can be observed and the highest value of KM is for laccase immobilized onto nanotubes. The efficiency is similar to the one for the enzyme immobilized onto paper.

\section{Acknowledgement}

This study has been financially supported by the Operational Programme "Science and education for smart growth" 20142020 of the European Union cofounded by the European Social Fund through the project BG05M2OP0012.0090015 "Support for the development of capacity of doctora students and young researchers in the field of engineering, natural and mathematical sciences".

The part of this study including synthesis, characterization and selection of the membranes for improvement the suitable properties of biomolecule immobilization was financially supported by project DN 07/21 FUND "Scientific Investigations", Bulgaria.

\section{References}

1. Lejeune A, Deprez T (2010) Cellulose: Structure and Properties, Derivatives and Industrial Uses. Nova Science Publishers, Incorporated.

2. Koon-Yang L (2018) Nanocellulose and Sustainability: Production, Properties, Application and Case Studies. CRC Press Taylor and Francis Group.

3. Saito T, Kimura S, Nishiyama Y, Isogai A (2007) Cellulose Nanofibers Prepared by TEMPO-Mediated Oxidation of Native Cellulose. Biomacromolecules 8: 2485-2491.

4. Mishra S, Manent A, Chabot B, Daneault C (2011) Production of nanocellulose from native cellulose - various options utilizing ultrasound. Bioresources 7: 422-436.

5. Salajkova M, Valentini L, Zhou Q, Berglund L (2013) Tough nanopaper structures based on cellulose nanofibers and carbon nanotubes. Composites Science and Technology 87: 103-110.

6. Hamedi M, Karabulut E, Marais A, Herland A, Nyström G, et al. (2013)
Nanocellulose aerogels functionalized by rapid layer-by-layer assembly for high charge storage and beyond. Angew Chem Int Ed Engl 52: 12038-12042.

7. Decher G (1997) Fuzzy Nanoassemblies: Toward Layered Polymeric Multicomposites. Science 277: 1232-1237.

8. Decher G, Schlenoff JB (2012) Multilayer Thin Films-Sequential Assembly of Nanocomposite materials. (2nd ed), Wiley-VCH, Weinheim, Germany.

9. Wilson R, Turner APF (1992) Glucose oxidase: An ideal enzyme. Biosensors \& Bioelectronics 7: 165-185.

10. Barrière $F$, Kavanagh $P$, Leech $D$ (2006) A laccase-glucose oxidase biofue cell prototype operating in a physiological buffer. Electrochimica Acta 51: 51875192.

11. Christwardana M, Jae K, Kwon $Y$ (2016) Fabrication of Mediatorless/ Membraneless Glucose/Oxygen Based Biofuel Cell using Biocatalysts Including Glucose Oxidase and Laccase Enzymes. Scientific Reports 6: 30128.

12. Kim RE, Hong SG, Ha S, Kim J (2014) Enzyme adsorption, precipitation and crosslinking of glucose oxidase and laccase on polyaniline nanofibers for highly stable enzymatic biofuel cells. Enzyme Microb Technol 66: 35-41.

13. Johannes C, Majcherczyk A (2000) Laccase activity tests and laccase inhibitors. J Biotechnol 78: 193-199.

14. Godjevargova T, Nenkova R, Konsulov V (2006) Immobilization of glucose oxidase by acrylonitrile copolymer coated silica supports. J Molecular Catalysis B Enzymatic 38: 59-64.

15. Qi W, Yan X, Duan L, Cui Y, Yang Y, et al. (2009) Glucose- Sensitive Microcapsules from Glutaraldehyde Cross-Linked Hemoglobin and Glucose Oxidase. Biomacromolecules 10: 1212-1216.

16. Mishra S, Thirre J, Manent A, Chabot B, Daneault C (2012) Ultrasoundcatalysed TEMPO-mediated oxidation of native cellulose for the production of nanocellulose: Effect of process variables. Bioresources 6: 121-143.

17. Anderson R, Guan J, Richard M, Dubey G, Su J, et al. (2010) Multifunctional single-walled carbon nanotube -cellulose composite paper. J Mater Chem 20: 2400-2407.

18. Datsyuka V, Kalyva M, Papagelis K, Parthenios J (2008) Chemical oxidation of multiwalled carbon nanotubes. Carbon 46: 833-840.

19. Lowry OH, Rosebrough NJ, Farr AL, Randall RJ (1951) Protein measurement with the Folin phenol reagent. J Biol Chem 193: 265-275

20. Yotova L, Manova D, Dessislava M, Borisov BG (2000) Production and characterization of lipase from pseudozyma antarctica NBIMCC 8340

21. Grunwald P (2009) Biocatalysis: Biochemical Fundamentals and Applications.

22. Hannoun BJ, Stephanopoulos G (1986) Diffusion Coefficients of Glucose and Ethanol in Cell-free and Cell-occupied Calcium Alginate Membranes. Biotechnology and Bioengineering 28: 829-835.

23. Zeng H, Tang Z, Liao L, Kang J, Chen $Y$ (2011) Electrochemistry of ABTS at Glassy Carbon Electrodes. Chinese J Chem Phy 24: 653-658. 